http://kitaibelia.unideb.hu/

ISSN 2064-4507 (Online) • ISSN 1219-9672 (Print)

(C) Department of Botany, University of Debrecen, Hungary

24(2): 153-164.; 2019

DOI: $10.17542 /$ kit.24.153

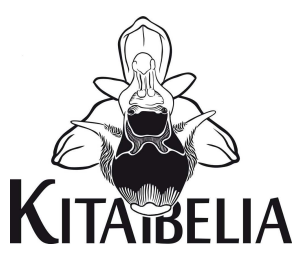

\title{
Magyarországon előforduló idegenhonos tóalma (Ludwigia) fajok taxonómiai revíziója
}

\author{
MESTERHÁZY Attila ${ }^{1}$, RIEZING Norbert ${ }^{2}$ \& VIDÉKI Róbert ${ }^{3}$ \\ (1) Hortobágyi Nemzeti Park Igazgatóság, H-4024 Debrecen, Sumen utca 2.; amesterhazy@gmail.com \\ (2) H-2851 Környe, Koltói A. út. 6. \\ (3) H-9794 Felsőcsatár, Petőfi út 13.
}

\section{Taxonomic revision of alien Ludwigia species in Hungary}

\begin{abstract}
Some tropical Ludwigia species have been planted as ornamentals in Hungarian thermal springs since the 1920s. Although they have become naturalised or even invasive in a few places, their specific identity remained generally uncertain. Our herbarium and field studies revealed that three species of alien water-primroses occur in Hungary. The most frequently planted one is Ludwigia repens, which is, however, a sporadic species in its native distribution area. We have found this species in several parts of the country. Although a few escaped and self-sustaining populations were also observed, this species has appeared to be non-invasive so far. Ludwigia grandiflora appeared in Hungary at the beginning of the 2000s. At the moment it is known from three localities, though spreading rapidly, becoming already invasive in its locality at Tata city. A similar species, L. peploides has recently been reported from two localities, where it forms small stands; the success of its naturalisation can be assessed in the future. We found no evidence for the Hungarian occurrence of $L$. alterniflora that had been published from Eger city. Therefore we suggest deleting this species from the current Hungarian checklist.
\end{abstract}

Keywords: alien species, aquatic ornamental plant, hot spring, Hungarian flora

Összefoglalás - A dísznövényként kedvelt trópusi tóalma fajokat Magyarországon már az 1920-as évektől kezdődően ültették egyes melegvizes forrásokba. Ezek több helyen elvadultak, illetve néhány esetben invázióssá váltak. A hazánkban talált fajokat egyes munkák eltérő neveken közölték, az egyes helyeken lévő populációk faji azonosítása sem történt meg. Herbáriumi és terepi vizsgálataink során világossá vált, hogy Magyarországon az adventív tóalmáknak 3 fajuk található meg. A Ludwigia repens bár élőhelyein szórványosan fordul elő, ezt a fajt ültetik leggyakrabban. Állományait az ország több pontján is megtaláltuk. Bár a faj kivadul és egyes helyeken önfenntartó populációkkal rendelkezik, terjedése mégsem okoz problémát. A L. grandiflora a 2000-es évek elején jelent meg hazánkban. Napjainkban 3 helyen fordul elő és mindegyik lelőhelyén nagymértékű terjedése figyelhető meg. A hozzá hasonló L. peploides a közelmúltban került elő az ország két pontjáról. Egyelőre csak kis állományokban található meg, így meghonosodásának jellege csak évek múltán lesz értékelhető. A korábban Egerből közölt L. alterniflora, hazai előfordulására nincs bizonyíték, így javasolt törlése a hazai flórából.

Kulcsszavak: adventív fajok, magyar flóra, melegvizes források vízinövények, vízinövény kereskedelem 


\section{Bevezetés}

A trópusi és szubtrópusi régiókban elterjedt Ludwigia L. nemzetség mintegy 82 fajt foglal magába (RAVEN 1963, RAMAMOORTHY-ZARDINI 1987), ezek jelentős része az Újvilág trópusi és szubtrópusi területein honos. Európában egyetlen fajuk a közönséges tóalma (Ludwigia palustris L.) őshonos, mely hazánkban a Dél- és Délnyugat-Dunántúl ritka növénye. A 20. században a dísznövénykereskedelem intenzívvé válásával több, elsősorban Amerikából származó mutatós faj került az európai akvakultúrákba, ahonnan néhányuk elvadult. Jelenlegi ismereteink szerint kontinensünkön a következő idegenhonos fajok rendelkeznek önfenntartó populációkkal: L. repens J.R. Frost., L. peploides (Kunth) Raven, L. grandiflora (Michaux) Greuter et Burdet, L. hyssopifolia (G. Don) Exell (FERRER-LAGUNA 2009, HuSSNER 2012). Ezek közül a L. peploides és a L. grandiflora Nyugat-Európa egyes helyein terhes, inváziós gyommá vált (DENDELOT et al. 2005).

Magyarországon - elsősorban melegvizes forrásokban és azok kifolyóiban - már az 1900as évek közepén feltűntek az idegenhonos tóalma fajok, melyeket többnyire kerti dísznövényként ültettek be. A megtalált fajokat azonban flóraműveink az idők folyamán eltérő neveken közölték.

Az adventív tóalmák első közlése Soó (1966) munkájában található, melyben a L. repens és L. alternifolia fajokat említi Miskolc-Tapolcáról, illetve Egerből. FELFöLDY (1990) már Miskolc-Tapolcáról a L. peploides-t hozza és a L. repens-t annak szinonimjaként tünteti fel. A leírás alapján azonban a növény egyértelműen a szórt levélállású fajokra ( $L$. peploides, $L$. hexapetala) illik, viszont Miskolc-Tapolcán ezeket soha nem találták. Simon (2000) flóraművében már csak szórt levélállású fajokat (L. uruguayensis (Camb.) Hara ill. L. peploides) találunk ugyanezekről a helyekről. A Füvészkönyv (KIRÁLY 2009) szintén két fajt közöl: a L. peploides-t Hévízről, míg a L. repens-t az ország több melegvizes kifolyójából. Előbbi faj $L$. uruguayensis-re történő helyesbítése később történt meg (KIRÁLY et al. 2011). Legújabban LUKÁCS et al. (2016) foglalkoztak a Magyarországon található adventív vízinövényekkel. Ebben a munkában a szerzők 2 fajt meghonosodottnak (L. repens, L. grandiflora), míg a L. alternifolia-t alkalmilag kivaduló növénynek tartják.

Látható tehát, hogy az egyes összefoglaló munkák a hazánkban megjelenő fajokat eltérő neveken közölték és az egyes helyekről kimutatott fajok száma is változott. Ezért fontosnak láttuk a hazánkban előforduló adventív tóalmák pontos beazonosítását és lelőhelyeik pontosítását.

\section{Anyag és módszer}

A tóalma fajok hazai gyűjtéseit a Magyar Természettudományi Múzeum Növénytárában (BP), az ELTE Füvészkert (BPU) és a Debreceni Egyetem (DE) herbáriumában vizsgáltuk meg. Terepbejárásaink során a 2018-2019-es években az irodalmi adatokban és a herbáriumi lapokon található lelőhelyeket ellenőriztük, hogy megállapítsuk a fajok jelenlegi elterjedését. A fajok beazonosítását RAVEN (1963), CLEMENT (2000), JACONO (2017) és VERLOOVE (2013) munkái alapján végeztük.

\section{Eredmények}

Vizsgálataink alapján Magyarországon az őshonos L. palustris mellett 3 adventív tóalma faj él, melyeket beillesztettünk a legújabb flóramű (KIRÁLY 2009) határozókulcsába. 
1a A levelek szórt állásúak, a virág hosszú kocsányú 2

1b A levelek átellenesek, a virág ülő v. rövid kocsányú........................................................................... 3

2a A csésze a termésen 0,8-1,2 cm, a szirom 1-1,5 cm. A szárlevél lapát alakú, $2 \times 3$ hosszabb a szélessségénél. T: 20-100 cm. HH (He). VI-X. Adv. (Am). Meleg vizek kifolyóiban (Tata, Detk).

L. peploides (Kunth) Raven

2b A csésze a termésen $\geq 1,5 \mathrm{~cm}$, a szirom 2-2,5 cm. A szárlevél lándzsás, legalább $5 \times$ hoszszabb a szélességénél. T: 20-100 cm. HH (He). VI-X. Adv. (Am). Meleg vizek kifolyóiban (Tata, Hévíz, Gárdony).

L. grandiflora (Michx.) Greuter \& Burdet

3a A szirom hiányzik. A termés 4-6 mm hosszú, csaknem ülő, vagy rövid 1-3 mm hosszú kocsányú. A levél 1-5 cm hosszú, széles lándzsás v. tojásdad, hirtelen nyélbe keskenyedő. T: 5-30 cm. HH (Th-He). VI-IX. Mészkerülő. Lassan folyó vizek, tócsák, iszaptársulások, kavicsfelszínek. NyDt (É-ra a Rábáig), DDt (Belső-Somogy) ritka, erősen visszaszorulóban.

L. palustris L.

3b A szirom 2-3 mm hosszú (a csészénél rövidebb), sárga. A termés 7-12 mm hosszú, a kocsány 5-7 mm hosszú. A levél 4-7 cm hosszú, lándzsás, vagy tojásdad, hosszan nyélbe keskenyedő. T: 30-50(-80) cm. HH (Th-He). VI-IX. Adv. (ÉAm és Közép-Am.). Meleg vizekben, ritkán elvadul (Miskolctapolca, Eger, Tata, Tapolca, Dunaalmás, Budapest).

L. repens J.R. Frost

A Ludwigia alternifolia L. természetes előfordulási helye Észak-Amerika keleti fele, KözépAmerika és Dél-Amerika északi része. Első említése 1940-ből származik az egri fürdőből, ahová betelepítették (Soó 1966, SuBA 1983). SuBA (1968) még csak a strand területén lévő medencékből említi a fajt, FELFÖLDY (1990) szerint a fürdő levezető csatornájában meghonosodott. Suba János egy későbbi munkájában (SuBA 1983) a növényről egy rajzot is közöl, melyen egy szórt levélállású, termés és virág nélküli növény látható. Herbáriumi példánya egyik vizsgált gyűjteményben sem található. Jelenlegi kutatásaink 2019-ben az egri fürdő területén nem erősítették meg előfordulását. Mindezek alapján a L. alternifolia hazai előfordulása bizonytalan. Feltételezhetően a hozzá hasonlóan szórt levélállású L. grandiflora-val téveszthették össze, melyet az akvaristák előszeretettel forgalmaztak korábban is Európában. A L. alternifolia ezzel szemben nem egy elterjedt akváriumi dísznövény. Az egrihez hasonló kivadulását csak az Alsó-Ausztriai Villach termálfürdő levezető csatornájában figyelték meg, de később a herbáriumi példány vizsgálata alapján kiderült, hogy az innét közölt faj a $L$. repens-szel azonosítható (HARTL et al. 1994).

Ludwigia grandiflora (Michx.) Greuter \& Burdet (1. ábra) (Syn.: Jussiaea grandiflora Michx., J. michauxiana Fernald,

L. clavellina var. grandiflora (Michx.) M. Gómez, L. uruguayensis (Camb.) H. Hara)

Újvilági szubtrópusi faj, amely Dél-Amerikában és Közép-Amerika egyes országaiban (Costa Rica, Kuba), valamint az Egyesült Államok DK-i részén őshonos (RAVEN 1963).

ZARDINI et al. (1991) kariológiai vizsgálatok alapján kimutatta, hogy az addig egy taxonként kezelt Ludwigia uruguayensis (CAMBESS.) HARA (syn.: L. grandiflora) két dekaploid (L. hexapetala) és hexaploid (L. grandiflora s.str.) alakot foglal magába. Mindkét faj morfológiailag eléggé egyöntetű, ezért egyes szerzők (NESOM \& KARTESZ 2000) a L. hexapetala-t csak alfaji szinten különítik el a L. grandiflora-tól. A előbbi taxon virágainak részei nagyobbak, illetve úszó levelei hosszúkás alakúak, míg utóbbié lándzsásak, lándzsás-elliptikusak. A L. hexapetala szárleveleinek levélnyele hosszabb, mint a L. grandiflora-é, utóbbinak szárlevelei majdnem ülők. 
Bár mindkét fajt tartják európai akvakultúrákban (HocH 1997), közülük csak a Ludwigia hexapetala vált invázióssá (WAGNER et al. 2007). Legújabb kutatások (ARMITAGE et al. 2013) szerint Nagy-Britanniában csak a L. hexapetala található meg kivadulva. A hazai populációk a morfológiai bélyegek alapján inkább a L. hexapetala-hoz állnak közelebb, azonban a pontos azonosításhoz további kariológiai vizsgálatok szükségesek.

A fajt először Franciaországban Montpellier mellett találták az 1800-as évek második felében (RAVEN 1963). Napjainkra Nyugat-és Dél-Európa különböző országaiban ismertek kivadulásai. Egyes helyeken (Hollandia, Belgium, Németország, Franciaország) terhes gyommá vált (DENDElot et al. 2005, Nehring \& KolthofF 2011, VerLoOve 2013).

Hazánkban először a Hévízi-csatorna egyik mellékágában (Óberek csatorna) [9269/1] Nagy Attila és Vidéki Róbert találta a fajt 2005-ben (Nagy A. \& Vidéki R. ined.). Az érintett csatorna egy jelentősen elnádasodó, lassú folyású víztest, melynek partjain Glyceria maxima és Carex riparia alkot szegélyvegetációt. A csatorna hőmérséklete alacsonyabb, mint a forrástó területéről kiinduló Hévízi-csatornáé. Utóbbi helyen a faj nem él. Az Óberek-csatornában a tóalma napjainkban is megtalálható: többnyire a víz nyílt részein alkot összefüggő állományokat kb. 200 m hosszan. A csatorna erős feltöltődést mutat, a part felől a széleslevelű- és a keskenylevelü gyékény (Typha latifolia, T. angustifolia) valamint a nád (Phragmites australis) erős terjedése tapasztalható. A tóalma a mocsári növényzettel kolonizált részekről kiszorult, jelenleg a nyíltvizes foltokban fordul elő, de a csatorna jelentős részéről a szintén adventív Gymnocoronis spilanthoides kiszorította. A L. grandiflora kis foltokban a Lotus Therme Hotel menti melegvizes vízlevezető árokban is előfordul, bár innét az utóbbi években próbálták eltávolítani.

Az Által-ér völgyében elsőként a Kecskédi-tóból [8475/4] került elő 2007.07.25-én néhány virágzó példánya egy nádas szegélyből, de innen azóta eltűnt. A tavat tápláló OroszlányKecskédi-vízfolyás felsőbb szakaszán, a tótól mintegy 1,3 km távolságban található szennyvíztelepen próbálkoztak a növény megtelepítésével. A tóban talált példányok feltehetően innen kerültek ki.

A tatai Fényes-források területén dekorációs célból tószegélybe ültették a 2000-es évek elején számos más idegenhonos dísznövénnyel (Houttuynia cordata, Lobelia cardinalis, $L$. siphilitica, L. × speciosa, Saururus cernnus stb.) együtt. A növények mára innen eltűntek.

Később a Fényes-patak mentén bukkant fel Naszály határában a Ferencmajori-halastavakra vezető híd környezetében [8375/2], feltehetően szándékos telepítés eredményeként. A faj a különböző években változó egyedszámban, de mindig csak kisebb folton jelent meg. Az utóbbi években a célirányos keresés ellenére sem került elő. Megjelent ugyanakkor innen mintegy 2 kilométerre, a Fényes-patak felsőbb, Réti-malom (Tata) és a Ferencmajori-halastavak előtti zsilip (Naszály) közötti szakaszán. A 2018. augusztusi felmérés során egy kb. 730 méteres szakaszon már teljesen beborította az egész vízfelületet. A növények többségét szeptemberben mechanikus úton eltávolították, de a szegélyekben megmaradt. A helyiek elmondása alapján már 2016-ban tömeges volt a növény. A tóalma minden bizonnyal a Réti-malom mellett található vízinövénykertészetből szabadult ki.

Az Által-ér vértesszőlősi részén [8376/3] elsőként Schmidt Dávid észlelte a nagyvirágú tóalmát (2018. augusztus), mely az ezt követő felmérés során a vízfolyás Tatabánya és Tata közötti, mintegy 3,1 km hosszú szakaszáról került elő (Riezing N. ined.). Mintegy 2,4 km-es szakaszon a tóalma teljesen átszőtte a víztestet, sőt sokfelé a nádas-gyékényes foltokban és a vízparti rézsűn is megjelent. A két hónappal korábban, 2018. június 12-én készült légi felvételen a nagyvirágú tóalma már tömeges, de még nem borítja be a teljes vízfelületet, illetve az érintett szakasz is jóval rövidebb. A növények nagy részét a nyár végén mechanikus úton eltávolították, de a patak szélein jelentős egyedszámban megmaradt.

A Gárdony településhez tartozó Gárdonyi-árok kisvízfolyás mentán [8877/2] a BioAqua Pro Kft. munkatársa (Hődör István) VKI szempontú makrofita felmérést végzett 2015. au- 
gusztus 25-én és 2016. május 10-én 6 mintavételi területen, melyek közül kettőnél észlelte a Ludwigia grandiflora jelenlétét. A felmérés alapján az egyik területen (EOV_X: 618265; EOV_Y: 205745) 2015. augusztusában 11\%-os $\left(22 \mathrm{~m}^{2}\right)$, 2016 májusában pedig 12\%-os $\left(24 \mathrm{~m}^{2}\right)$ borítási értékeket rögzített. A másik területen (EOV_X: 618403; EOV_Y:205551) pedig mindkét időpontban 1\%-os (azaz kevesebb mint $2 \mathrm{~m}^{2}$ ) borítási érték mellett észlelte a fajt. A felmérés alapján az első területen a faj kis mértékű terjedése volt megfigyelhető. A vizsgált szakaszoknak Berula erecta és Glyceria notata dominálta dombvidéki kisvízfolyás jellege volt. Jellemző fajok gyakorisági sorrendben a következők: Berula erecta, Glyceria notata, Ludwigia grandiflora, Phragmites australis, Ranunculus repens, Veronica beccabunga, Alisma plantago-aquatica, Carex vulpina, Equisetum arvense, Glyceria maxima, Mentha aquatica, Poa palustris, Ranunculus sceleratus, Rumex crispus, Sagittaria sagittifolia, Symphytum officinale, Typha angustifolia, Typha latifolia.

Korábban ebből a vízfolyásból a Ludwigia repens került megfigyelésre (Kaszti \& Vidéki 2006 ined.), de aktuálisan innét jelenleg csak a L. grandiflora került elő. Feltehetően a robosztusabb nagyvirágú tóalma fokozatosan kiszorította az előbbi fajt.

Herbáriumi adata:

Király G. et al. Zala megye, Hévíz, a Hévízi-tótól DK-re 1 km-re, az Óberek-csatornán, 107 m s. m. (9269.1), 2009.07.27. (BP)

\section{Ludwigia peploides (Kunth) Raven (1. ábra)}

(Syn.: Jussiaea californica (S. Watson) Jeps., J. peploides Kunth, L. adscendens var. peploides (Kunth) H. Hara, L. clavellina var. peploides (Kunth) M. Gómez)

Újvilági szubtrópusi faj, amely Dél- és Közép-Amerika nagyrészén, valamint az Egyesült Államok déli és délkeleti államaiban fordul elő őshonosan. Észak-Amerika más részein gyorsan terjedő invazív faj (uswildflowers.com). Európában behurcolták Belgiumba, Görögországba, Hollandiába, Franciaországba, Nagy-Britanniába, Olaszországba és Spanyolországba. A közelmúltban Horvátországból is előkerült (BUZJAK \& SEDLAR 2018). Erős kompetítor, veszélyes özönnövény. Franciaország egyes mediterrán területein a korábban szintén inváziós L. grandiflora-t is kiszorította (DANDELOT et al. 2005).

Bár a faj szerepel az Új Magyar Füvészkönyben (KIRÁLY 2009), valójában az ott szereplő adata (Hévíz) a L. grandiflora-ra vonatkozik (KIRÁLY et al. 2011). A növényt először 2010-ben találtuk a visontai lignitbánya melletti Tarnóca-patak medrében, közel a 33-as úthoz [8286/4] (Mesterházy A. ined.). A bányaterületen átfolyó patakba a bányából rendszeres rétegvízbetáplálás történik, így az itteni szakasz vize a patak felsőbb szakaszainál melegebb. A rétegvízbetáplálás közelében a 2000-es évek elején a L. peploides mellett több melegvízi hínárfajt is betelepítettek vagy spontán megtelepedett (Lagarosiphon major, Myriophyllum aquaticum, Azolla filiculoides, Lemna minuta). A bányászat miatt a Tarnóca-patak medrét 2016-ban áthelyezték, így a régi mederbe már a korábbinál jóval kevesebb víz folyik. A thermofita fajok közül ma már csak a L. peploides fordul elő, mely a betáplálás közelében alkot néhány $\mathrm{m}^{2}$-es állományt. Kisebb foltokban a híd közelében is megtalálható, de a híd alatti szakaszon már nem fordul elő.

A Tatától északra található Fényes-patak Fényes-források alatti szakaszáról [8375/2] 2018. szeptemberében került elő (Riezing N. ined.) Kisebb-nagyobb foltjai egészen a Ferencmajori-halastavak elôtti zsilipig (Naszály) megtalálhatók. Jelentősebb állománya a Réti-malomnál (Tata) alakult ki a L. grandiflora tömegébe ágyazódva, de attól elkülönülve. 
Herbáriumi adata:

Mesterházy A. Heves megye, Detk, 33-as út hídja a Tarnóca-patak egykori ágánál, a rétegvíz betáplálás környékén. 2017.08.31. (BP)

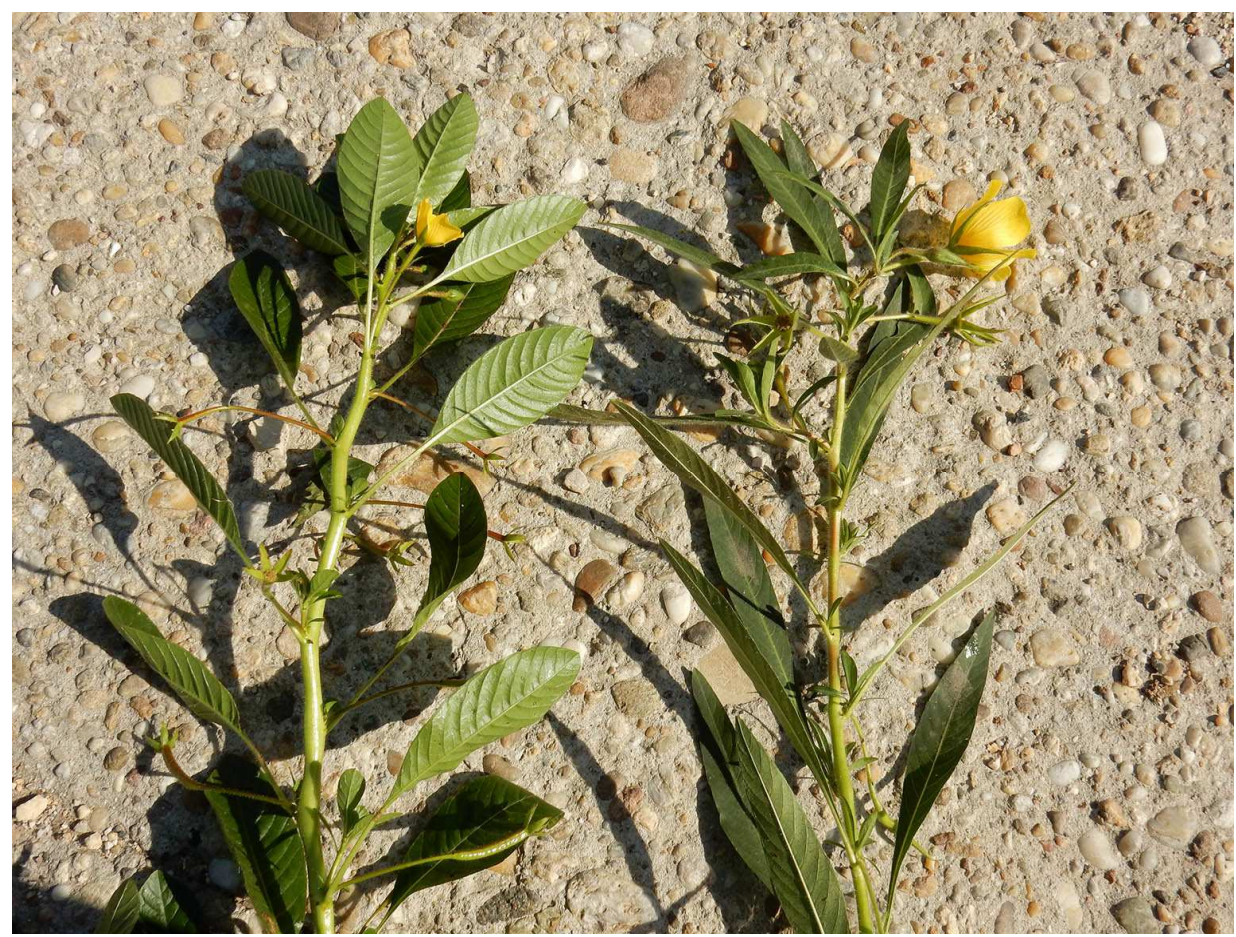

1. ábra A L. peploides (balra) és L. grandiflora (jobbra) Tatáról (Riezing N. felvétele) Fig. 1 L. peploides (left) and L. grandiflora (right) at Tata city (photo by N. Riezing)

\section{Ludwigia repens J.R. Frost (2. ábra)}

(Syn.: L. natans Elliot)

Az Egyesült Államok déli részén, Közép-Amerikában és a karibi térségben elterjedt faj. Európában adventív fajként megjelent Spanyolországban (CirujAno et al. 2014), Ausztriában (FISCHER et al. 2005) és Magyarországon (Soó 1966).

A L. palustris-szal alkotott természetes hibridjét a L. × kentiana E.J. Clement-t először Angliában azonosították (CLEMENT 2000), majd később Németországból (DUNKEL et al. 2007) és Svájcból (MARIE-LAMBELET 2017) is előkerült.

A fajt hazánkban elsőként BoRos (1937; BP conf. in litt. 1943 Soó) találja 1924-25-ben a Miskolc-Tapolcai fürdő (Görömböly-Tapolca) [7990/1] hőforrások környékének és kifolyójuk vegetációjának tanulmányozása során. Az általa nem ismert Ludwigia faj „úgy elszaporodott, hogy írtani kell”. Soó (1943) a Bükkhegység flóralistájának összeállításában megemlíti Boros korábbi megfigyelését és a taxont Ludwigia repens Swartz-ként azonosítja. A belvizes laposok vegetációjáról összeállított dolgozatában (Soó 1946) szintén említést tesz az amerikai származású Ludwigia repens-ről és a Synopsisba (1966) „meleg vizű tavakban ültetett és elszaporodó fajként" veszi fel. A fajt a tapolcai helyszínen később több hazai botanikusunk is gyűjti: Jávorka S. (1944 BP); Boros Á. (1947 BP); Papp J. (1947 BP); Horánszky A. (1947 BP); Moldvai R. (1950 BP). A herbáriumi adatok tanúsága szerint a korabeli előfordulások nem 
csak a kifolyó környékére korlátozódtak, hanem a faj megjelent a Hejő-patakban is. A 2000es évek elején itt még megvolt a fürdő előtti park mesterséges tavaiban (Danyik \& Vidéki 2006 ined.), de 2018-ban már nem találtuk.

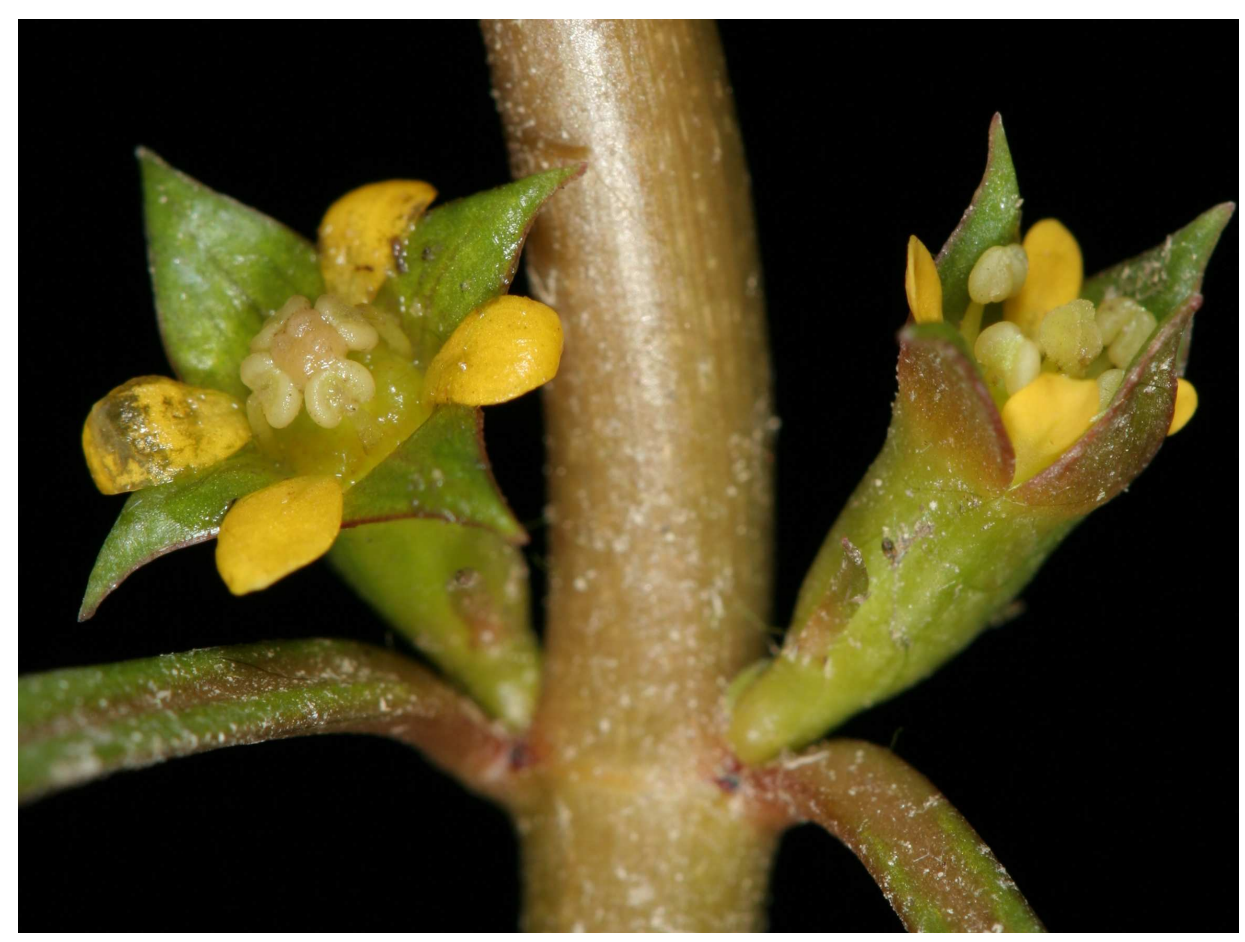

2. ábra A L. repens virágzata (Vidéki R.)

Fig. 2 Inflorescence of L. repens (photo by R. Vidéki)

Az egri termálfürdő területén lévő kis medencékben [8188/1] Boros Ádám 1959-ben már gyüjti a fajt (1959; 1960 BP), és SuBA (1968) is jelzi, de tévesen a hazai Ludwigia palustrisszal azonosítja és megjegyzi, hogy az is „jól fejlődik itt”. Későbbi tanulmányában szintén említést tesz róla (SUBA 1983) hasonló megjegyzéssel. Kis állománya még napjainkban is megtalálható a vízköpő kisebb medencéjében és a fürdő nyugati részén lévő kis betonmedencékben, más thermofita fajok (Sagittaria subulata, Hygrophyla polysperma, Vallisneria spiralis) mellett. VojTKó (2001) a Bükk hegység flórájáról készített összefoglaló munkájukban részben korábbi herbáriumi és irodalmi, részben saját terepi megfigyelésekre hivatkozva (évszám nélkül, L-V azaz Less \& Vojtkó) említik a L. repens-t, Tapolcáról (Miskolctapolca) a L. peploides-t Egerből, valamint a L. uruguayensis-t szintén Tapolcáról (Miskolctapolca). A herbáriumi adatokon végzett revízió alapján az utóbbi két taxon is L. repens-nek bizonyult.

A fajt Budapest néhány melegvizes medencéjébe is betelepítették a 2000-es években. Ilyen jellegű előfordulásait a Lukács-fürdő előtti Germanus parkból, a Malom-vendéglő melletti tóban és a Margit-szigetről ismerjük (Vidéki R. ined.) [8480/3]. Utóbbi helyen 2019-ben már nem volt meg. A herbáriumi adatok tanúsága szerint az ELTE Botanikus Kertben is volt egy állománya (Papp J. 1948), de napjainkban itt sem található már meg. A tapolcai Malom tóból és a tóból eredő Tapolcai-patak felső szakaszán először 2006-ban került elő (Vidéki R. ined.) [9171/2]. A Tapolca-patakból később a medertisztítások miatt teljesen eltûnt. A Malom-tóban viszont még ma is megtalálható, itt a hasonlóan betelepített Vallisneria sprialis, $V$. gigantea, Egeria densa, Rotala rotundifolia, Sagittaria subulata fajokkal él együtt. 
Gárdony település mellett található Gárdonyi-árokból, a termálfürdő kifolyójánál 2006ban találták meg továbbszaporítási céllal, betelepítésből származó jelentôs állományát (Kaszti \& Vidéki 2006 ined.) [8877/2]. Később ide a L. grandiflora-t is betelepítették, mely napjainkra a fajt teljesen kiszorította.

Dunaalmáson az Által-ér egykori torkolatánál [8275/4] egy jelentős állományát találtuk 2018-ban. A faj itt a patak szegélyében és sekély vizében, többnyire árnyékos helyeken fordul elő, őshonos mocsári növényzettel (Berula erecta, Myosotis palustris) együtt.

Tatán a Fényes-források területének néhány tavából, illetve a Fényes-patak tatai szakaszáról került elő (Mocsi \& Vidéki 2006 ined.) (RIEZING 2008) [8375/2]. Utóbbi területen vöröses levelű példányai is vannak. A növényt már az 1990-es évek elején is telepítették (Kugli ex verb.). MATUS et al. (1998) kéziratos dolgozatában található L. palustris adat minden bizonynyal a $L$. repens-re vonatkozik.

A közeli Szomódról is van egy 2004-es gyüjtése [8376/1], egy mesterségesen tóvá duzzasztott vizes árokból, ahol más idegenhonos vízinövényeket (Pistia stratiotes, Myriophyllum heterophyllum) is termesztettek. A növényt itt korábban L. palustris-ként azonosították (BARINA 2006). A duzzasztást később megszűntették, ma a tó szárazon áll és a tóalma innét eltűnt (Barina Z. ex litt.). A faj hazai adatait korábban DANYIK et al. (2008) foglalták össze.

Herbáriumi adatai:

Budapest

Papp J. Ex. cult. In horto botanico Universitatis Sc. Hungaricae. Budapest 1948.09.25. (BP)

Király G. \& Dancza I. Budapest, 13. kerület, Margitsziget É-i oldalán, melegvizű kőmedencékben, 105 m s. m. (8480.3) 13.10.2006 (BP)

Miskolc-Tapolca

Boros Á. Comit. Borsod In lacu therm ad Görömböly-Tapolca. 1937.05.22. conf. in litt. 1943.03.15. Soó (BP)

Soó R. Cott. Borsod ina qua lacus thermalis pr. balneas G-Tapolca 1938.08. (DE, BPU)

Jávorka S. Görömbölyi Tapolca Miskolc mellett a nagy tóban. 1944.06.30. (BP)

Papp J. Görömbölytapolcai-tó. Comit Borsod. 1947.07.11. (BP)

Papp J. Sub radicibus montium Bükk. In lacu thermali Görömbölytapolca. Com. Borsod. dátum nélkül (BP)

Papp J. Görömbölytapolca ad Miskolc com Hung. centr. In fontibus termalis, (culta). 1947.07.11. (BP)

Horánszky A. Miskolc, Görömbölytapolca melegforrásaiban. 1947.07.11. (BP)

Boros Á. Comit. Borsod In rivulo thermali Hejő prope baln. Miskolc-tapolca (GörömbölyTapolca) 1947.07.17. (BP)

Moldvai R. Comit. Borsod; Miskolc-Tapolca, in lacu thermali 1950.08.22. (BP)

Eger

Boros Á. Comit. Heves. in aquis therm. ad. Eger 1959.09.04. (BP)

Boros Á. Comit. Heves. in aquis therm. balnei opp. Eger 1960.10.29. (BP)

Tata környéke

Barina Z. Szomód Községi-erdő; in summo lacu. 2004.08.18. (BP)

Hűvös-Récsi A. \& Matus G. Tata: Fényes-források 2006.11.08. (BP)

Tapolca

Király G. \& Király A. Veszprém megye, Tapolca, Tapolca-patak a 77 sz. út hídjánál a város belterületén, 116 m s. m. (9170.2) 2007.11.03. (BP) 
A Magyarországon megtalált idegenhonos tóalma fajok előfordulásai a legtöbb esetben olyan vízfolyásokhoz kötődnek, melyek a természetes felszín közeli forrásoknál melegebb víz betáplálásával érintettek. Ezek egyes termálfürdők melegvizes kifolyói, karsztforrások, hévízek, rétegvíz bevezetéssel érintett patakok. Az Által-ér Tatabánya és Tata közötti szakaszán ugyanakkor nincsenek melegvízű források, márpedig a L. grandiflora itt is megtelepedett, sőt eddig itt okozta a legnagyobb problémát.

\section{A Ludwigia fajok mint özönnövények}

A tóalma fajok közül a kisvirágú L. repens Európában - így hazánkban - nem vált inváziós fajjá. Előfordulási helyein általában szórványos, szinte soha nem alkot összefüggő nagy állományokat.

Nem mondható el ugyanez a nagyvirágú Ludwigia fajokról. Ezek kedvelt, dekoratív, tág tűrésű, egyre népszerűbb kerti tavi növények. Könnyen beszerezhetők és a kereskedelem révén Európában gyorsan elterjedtek. Ökológiai igényeik és tulajdonságaik hasonlók, ezért a továbbiakban a hazánkból előkerült L. grandiflora és L. peploides taxonokat együtt jellemezzük.

Tág tưrésűek, melyek szinte mindenféle vízben megmaradnak, még az enyhén sós vizet is elviselik. Speciális gyökérzetüknek köszönhetően oxigénszegény környezetben is jól fejlődnek. Rendkívül gyorsan nőnek. Zöldtömegüket álló vagy lassan folyó vízben 15-20 nap alatt duplázzák meg. Elszaporodva igen nagy egyedsűrűséget érhetnek el. Terjedésük és gyors szaporodásuk elsősorban vegetatív úton történik. Oligotróf környezetben is megmaradnak, de gyors növekedésük elsősorban a tápanyagban gazdag vizekben figyelhető meg.

Bár mindkettő trópusi, szubtrópusi eredetű faj a fagyokat jól tűrik (EPPO 2011). A vízből kiemelkedő részek elég gyorsan elfagynak, de a víz alatti szervek átvészelik a nagyobb hidegeket is. Vizsgálataink alapján hajtásai a víztest néhány napig tartó teljes befagyását követően is életképesek maradnak, gyakran még a víz alatti levelek sem fagynak el. Ráadásul hazánkban elsősorban melegvizű források vizeiből kerültek elő, mely feltehetően valamilyen mértékben véd a téli fagyoktól. A víz hőmérsékletével szemben leginkább tágtürésű $L$. grandiflora az időnként befagyó Óberek-csatornában is jelentős állományban megtalálható. Öszszességében kijelenthetjük, hogy a hazai viszonyok között télálló növényekről van szó.

Képesek drasztikusan átalakítani a vízi ökoszisztémát. A víz felszínét tejesen beborítják és mintegy másfél méter mélységig a víztestet is tömötten átszövik, kiszorítva így az őshonos növényzetet illetve a vízben élő állatok jelentős részét. Sűrű szövevényük elzárja a fényt a vízi élőlények elől. Rontják a víz minőségét. Csökkentik a vízben az oldott oxigén mennyiségét: egyrészt akadályozzák a levegő és a víztest közötti oxigéntranszfert, másrészt speciális szerveikkel kivonják a vízből az oldott oxigént. Ez számos élőlény (például halak) megmaradása szempontjából igen lényeges. Különféle allelopatikus anyagokat juttatnak a vízbe, melyek megakadályozzák más fajok magvainak a csírázását, hajtásaik növekedését. Ezen felül elvonják más növények elől a növekedésükhöz szükséges tápanyagokat, valamint betegségeket terjeszthetnek. Megszűntetik a nyílt vízfelületeteket, így akadályozzák a halak, vízi madarak mozgását, táplálékszerzését. A sekély, időszakosan vízállásos rétekről kiszorítják a füveket, így ellehetetlenítik azok legeltetését. Az invazív tóalma tömeges megjelenésével akadályozza a vízi szabadidős tevékenységeket (hajózás, horgászat, fürdés), illetve a vízi szállítást és az öntözést. Megváltoztatja az érintett víztest tulajdonságait is. Sűrű szövevénye csökkenti az áramló víz sebességét, elősegíti a vízben lebegő hordalék ülepedését, így elősegíti a vízfolyások eliszapolódását, valamint növeli az árvízveszélyt. Az állóvizekben nagy zöldtömegének bomlásával gyorsítja az üledékképződést, erőteljes párologtatásával pedig segíti azok kiszáradását (SEARS et al. 2006, KELLY \& MAGUIRE 2009, EPPO 2011, NNSS 2016). 
A Ludwigia fajok ellen a leghatékonyabb védekezés, mint számos más esetben, itt is a megelőzés: meg kell akadályozni a természetes vizekbe kerülését. Ezt elsősorban a kereskedelem korlátozásával, ellenőrzésével, vagy mint ahogy erre már van példa (Franciaország, Belgium, Svájc), a növény forgalmazásának betiltásával lehet(ne) elérni.

Visszaszorításukra több módszer (elsősorban mechanikai és vegyszeres) létezik. A leghatékonyabb, ha ezeket egymással kombinálva használják. Kis kiterjedésű foltok estén a kézi eltávolítás a leghatékonyabb. Fontos, hogy a vízben levő részeket is óvatosan húzzuk ki. A bent hagyott, vagy letört darabok is életképesek és újabb fertőzést okozhatnak. Nagyobb területen a gépi eltávolítás válhat szükségessé, melyet célszerű a területen maradt egyedek kézi eltávolításával kiegészíteni. Itt is figyelni kell arra, hogy a növény darabjai életképesek és a gépekre, eszközökre tapadva, majd elszállítva másutt is problémát okozhatnak. A mechanikus, gépi eltávolítás során szinte mindig maradnak életképes darabok (gyökér, szár), melyek újra hajtanak. A vegyszeres irtást (ezek többnyire glifozát hatóanyagú szerek) leginkább a mechanikus eltávolítás után visszamaradt növényi részek elpusztítására javasolják (így jóval kisebb mennyiségben kell kijuttatni).

Hazánkban eddig csak a L. grandiflora okozott problémát, mely az Által-ér egyes szakaszain a víztestet teljesen átszőtte, a vízi ökoszisztémát drasztikusan megváltoztatta és olyan tömegessé vált, hogy a víz lefolyásának gátlásával már árvízvédelmi kockázatot jelentett. $\mathrm{Az}$ eset érdekesége, hogy legnagyobb mennyiségben egy nem temperált vízű szakaszon jelent meg. Pontosabban csak látszólag, ugyanis településeink elfolyó lakossági és ipari vizei jelentős mértékben növelhetik a természetes vizek hőmérsékletét. Az érintett szakasz vizét elsősorban Tatabánya elfolyó tisztított szenny- és ipari vizei melegítik, melyek segítik a növény áttelelését. A tóalma „berobbanásának” több tényező mellett véleményünk szerint elsősorban a vízben szállított nagy mennyiségú tápanyag lehetett az oka. Megfigyeltük, hogy a növényzettel benőtt szakasz alsó vége felé egyre több egyeden jelentek meg a különféle tápanyagok hiányának a jelei (elsárgult hajtások, torz növekedés, stb.). Más, tápanyagot szállító vizek hozzáfolyása utáni szakaszon, illetve az akkumulációs helyeken ezeket nem tapasztaltuk.

\section{Köszönetnyilvánítás}

Köszönet illeti Barina Zoltánt (TTM Növénytár), ifj Papp Lászlót (ELTE Füvészkert) és Takács Attilát (Debreceni Egyetem) a herbáriumi anyag rendelkezésére bocsájtásáért, Király Gergelyt (NYME-Sorpron) a kézirathoz füzött hasznos megjegyzéseiért és Filip Verloove-t (Botanical Garden Meise-Belgium) egyes irodalmak beszerzésért. Schmotzer András (Bükki Nemzeti Park Igazgatóság) a terepi felmérésben nyújtott segítséget. Köszönjük továbbá Hődör Istvánnak (Bioaqua Pro Kft.) a gárdonyi, illetve Schmidt Dávidnak a vértesszőlősi L. grandiflora adat közlésre való átengedését.

\section{Irodalom}

ARmitage J.D., Könyves K., BAiley J.P., David J.C. \& Culham A. (2013): A molecular, morphological and cytological investigation of the identity of non-native Ludwigia (Onagraceae) populations in Britain. - New Journal of Botany 3(2): 88-95.

Cirujano Bracamonte S., Meco Molina A., García Murillo P. \& Chirino Argenta M. (2014): Flora acuática española. Hidrófitos vasculares. - Real Jardín Botánico, CSIC, Madrid 320 pp.

BARINA Z. (2006): A Gerecse hegység flórájának katalógusa. - Magyar Természettudományi Múzeum és a Duna-Ipoly Nemzeti Park Igazgatóság, Budapest, 612 pp. 
Boros Á. (1937): Magyarországi hévizek felsőbbrendű növényzete. - Botanikai Közlemények 34(3-4): 85-118.

BuZJAK S. \& SEDLAR Z. (2018): Ludwigia peploides (Kunth.) P.H. Raven - Floating Water Primrose, a new species in Croatian flora from the list of invasive alien species of Union concern. - Natura Croatica 27(2): 351-356.

Clement E.J. (2000) Ludwigia $\times$ kentiana E.J. Clement: a new hybrid aquatic. - Watsonia 23(1): 167-172.

Clement E.J. (2001): Ludwigia grandiflora established at Barton-on-Sea (v.c. 11, S. Hants). - BSBI News 87: $52-54$.

Dandelot S., Verlaque R., Dutartre A. \& Cazaubon A. (2005): Ecological, dynamic and taxonomic problems due to Ludwigia (Onagraceae) in France. - Hydrobiologia 551: 131-136.

DANYIK T., VIDÉKI R. \& NAGY A. (2008): A piroslevelű tóalma (Ludwigia repens Swartz) és a Ludwigia peploides (Kunth) P.H. Raven Magyarországon. In: Aktuális Flóra- és Vegetációkutatás a Kárpát-medencében VIII. konferencia (Gödöllő, 2008. február 29. március 2.) posztereinek összefoglalói. Kitaibelia 13(1): 157.

Dunkel F., Amarell U. \& Kleinsteuber A. (2007): Ludwigia × kentiana E.J. Clement - eine verkante Ludwigia hybride seit 20 Jahren am Oberrhein. - Carolinea 65: 55-58.

EPPO (2011): Ludwigia grandiflora and L. peploides, Onagraceae - Water primroses. - OEPP/EPPO Bulletin 41: 414-418.

FELFöLDY L. (1990): Hínárhatározó. - Vízügyi Hidrobiológia, Aqua Kiadó, Budapest 18. 144 pp.

FERRER PP. \& LAGUNA E. (2009): Sobre Ludwigia hyssopifolia (G. Don) ExELL (Onagraceae) como integrante de la flora subespontánea valenciana. - Acta Botanica Malacitana 34: 228-230.

FisCHER M.A., ADLER W. \& OSWALD K. (2005): Exkursionsflora für Österreich, Liechtenstein und Südtirol. 2., verbesserte und erweiterte Auflage. - Land Oberösterreich, OÖ Landesmuseen, Linz, 1380 pp.

Hartl H., Kniely G., Leute G.-H., Niklfeld H. \& Perko M. (1992): Verbreitungsatlas der Farn- und Blütenpflanzen Kärntens. - Verlag des Naturwiss. Vereines für Kärnten, Klagenfurt, 451 pp.

Hoch P.C. (1997) Ludwigia. - In: CulLEN J. et al. (eds), The European Garden Flora, vol. 5. Cambridge University Press, Cambridge, pp. 347-348.

HUSSNER A. (2012): Alien aquatic plants in European countries. - Weed Research 52: 297-306.

JACONO C. (2017): Identification of common aquatic water primrose species (Ludwigia), in Florida. Fieldguide. - Univ. Florida.

Kelly J. \& Maguire C.M. (2009): Water Primrose (Ludwigia species) Exclusion Strategy and Invasive Species Action Plan. - Prepared for NIEA and NPWS as part of Invasive Species Ireland.

KIRÁLY G. (szerk.) (2009): Új magyar füvészkönyv. Magyarország hajtásos növényei. Határozókulcsok. Aggteleki Nemzeti Park Igazgatóság, Jósvafő, 616 pp.

KIRÁLY G., MolnáR V.A \& VIRÓK V. (szerk.) (2011): Új Magyar Füvészkönyv. Ábrák. - Aggteleki Nemzeti Park Igazgatóság. Jósvafő. 676 pp.

LuKÁCs B. A., MESTERHÁZY A., VidÉKI R. \& KiRÁLY G. (2016): Alien aquatic vascular plants in Hungary (Pannonian ecoregion): historical aspects, data set and trends. - Plant Biosystems 150: 388-395.

MAiRE A.-L. \& LAMBELET C. (2017): De l'aquarium à l'étang... Ludwigia × kentiana E.J. Clement, un nouveau taxon pour la Suisse. - Saussurea 46: 109-116.

VојтKó A. (szerk.) (2001): A Bükk hegység flórája. - Sorbus 2001 Kiadó, Eger, 340 pp.

MATUS G., JENEY E. \& BARINA Z. (1998): A tatai Fényes-fürdő és környékének botanikai értékei. - Kézirat.

NEHRING S. \& KolthofF D. (2011): The invasive water primrose Ludwigia grandiflora (MichauX) GREUTER \& BURDET (Spermatophyta: Onagraceae) in Germany: first record and ecological risk assessment. Aquatic Invasions 6(1): 83-89.

NESOM G.L. \& KARTESZ J.T. (2000): Observations on the Ludwigia uruguayensis complex (Onagraceae) in the United States. - Castanea 65(2): 123-125.

NNSS (2016): Water Primrose Ludwigia grandiflora. - A Management Guide for Landowners.

RAMAMOORTHY T.P. \& ZARDINI E.M. (1987): The systematics and evolution of Ludwigia sect. Myrtocarpus sensu lato (Onagraceae). - Missouri Botanical Garden, St. Louis, 128 pp.

RAVEN P.H. (1963): The old world species of Ludwigia (including Jussiaea), with a synopsis of the genus (Onagraceae). - Reinwardtia 6: 327-427.

RIEZING N. (2008): A hínárvegetáció változása az Által-ér vízgyűjtőjén a korábbi kutatások tükrében. Természetvédelmi Közlemények 14: 91-103.

SEars A.L.W., Meisler J. \& Verdone L.N. (2006): Invasive Ludwigia Management Plan for the laguna de Santa Rosa. - Sonoma County, California. 
Simon T. (2000): A magyarországi edényes flóra határozója. - Tankönyvkiadó, Budapest. 976 pp.

Soó R. (1943): Előmunkálatok a Bükkhegység és környéke flórájához. - Botanikai Közlemények 40(1-2): 169-221.

Soó R. (1946): Zur Systematik und Soziologie der Phanerogamen Vegetation der Ungarischen Binnengewässer V. (XVI. Die Ludwigia Arten.). - Annales Musei Historico-naturalis Hungarici 39(10): 167187.

Soó R. (1966): A magyar flóra és vegetáció rendszertani-növényföldrajzi kézikönyve 2. - Akadémiai Kiadó, Budapest, 655 pp.

SubA J. (1968): Az egri melegvizek növényei. - Acta Academia Paedagogia Agriensis, Nova Ser 6: 395415.

SuBA J. (1983): Az egri meleg vizek élővilága. - In: SuGÁR I. (szerk.), Eger gyógyvizei és fürdői, Heves Megyei Idegenforgalmi Hivatal, Eger, pp. 399-441.

Verloove F. (2013): Ludwigia L. - Manual of the Alien Plants of Belgium. Botanic Garden Meise, Belgium.

WagneR W.L., Hoch P.C. \& Raven P.H. (2007): Revised classification of the Onagraceae. - Systematic Botany Monographs 83: 1-240.

ZARdini E.M., Gu H. \& RAVEN P.H. (1991): On the separation of two species within the Ludwigia uruguayensis complex (Onagraceae). - Systematic Botany 16: 242-244.

Beérkezett / received: 2019. 04. 01. • Elfogadva / accepted: 2019. 05. 17. 